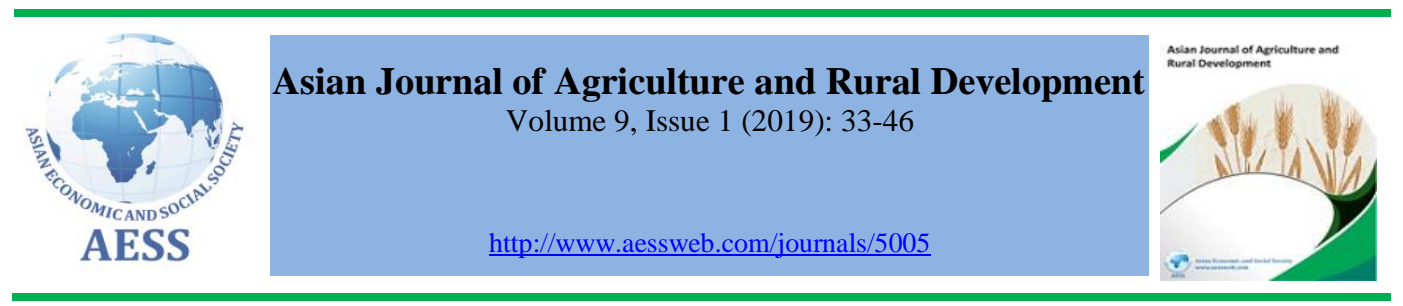

\title{
DETERMINANTS OF VIETNAM'S POTENTIAL TRADE: A CASE STUDY OF AGRICULTURAL EXPORTS TO THE EUROPEAN UNION
}

\section{Pham Hoang Linh $^{\mathrm{a}}$ \\ Nguyen Khanh Doanh $^{\text {b }}$}

Nguyen Ngoc Quynh $^{\mathrm{c}}$ a Lecturer; TNU-University of Economics and Business Administration, Thai Nguyen University, Vietnam

${ }^{\mathrm{b}}$ Associate professor; International School, Thai Nguyen University, Vietnam

${ }^{\mathrm{c}}$ International School, Thai Nguyen University, Vietnam

\ $₫$ phamhoanglinh@tueba.edu.vn (Corresponding author)

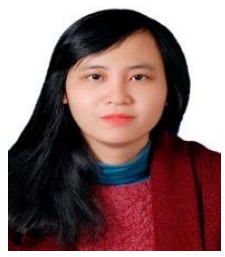

Corresponding author

\section{ARTICLE HISTORY:}

Received: 26-Feb-2019 Accepted: 04-Apr-2019 Online Available: $27-$ May-2019

\section{Keywords:}

Potential agricultural exports,

\section{Stochastic frontier}

Analysis,

System GMM,

Vietnam,

EU

\begin{abstract}
This study aims at quantifying the determinants of Vietnam's potential exports to the EU, taking agricultural commodities as a case study. In order to achieve this, we employed a stochastic frontier analysis to estimate Vietnam's potential agricultural exports, and a system GMM approach to analyze the determinants of the estimated potential agricultural exports of Vietnam. The results showed that Vietnam's potential agricultural exports to the EU have been high and on an upward trend. In addition, factors such as financial market development, trade freedom, technological readiness, and labor freedom have positive impacts on Vietnam's potential agricultural exports to the EU. Measures to improve the financial market development, remove trade barriers, increase technological capability, and promote labour freedom are strongly suggested in order to enable Vietnam's agricultural exports to attain its maximum level.
\end{abstract}

\section{Contribution of the Study}

This study is the first research on the determinants of Vietnam's potential agricultural exports to the European Union (EU) using a system GMM estimator. This approach allows us to get accurate estimates of the parameters because it allows us to overcome the problems of endogeneity, serial correlation, heteroskedasticity, and omitted important variables.

DOI: 10.18488/journal.1005/2019.9.1/1005.1.1.33.46

ISSN (P): 2304-1455/ISSN (E):2224-4433

How to cite: Pham Hoang Linh, Nguyen Khanh Doanh and Nguyen Ngoc Quynh (2019). Determinants of Vietnam's potential trade: a case study of agricultural exports to the European Union. Asian Journal of Agriculture and Rural Development, 9(1), 33-46.

(C) 2019 Asian Economic and Social Society. All rights reserved. 


\section{INTRODUCTION}

Agriculture is one of the key sectors, which has played an important role in Vietnam's economic development (GSO, 2017). According to the United Nations International Trade Statistics Database, agricultural products accounted for approximately $15 \%$ of Vietnam's total exports to the rest of the world (WITS, 2018). Among the main trading partners, the EU has emerged as the second largest market of Vietnam's agricultural exports ${ }^{1}$, making up $15.8 \%$ of Vietnam's total agricultural exports ${ }^{2}$. During the period of 2006-2016, Vietnam's agricultural exports to the EU have increased steadily, reaching an average growth rate of $9.1 \%$ per year ${ }^{3}$. However, agricultural exports to this market face a lot of difficulties, especially non-tariff barriers. These barriers definitely hinder Vietnam's agricultural exports from attaining its potential level. In order to overcome this problem, identifying and analyzing the determinants of Vietnam's potential exports are of paramount importance.

Following Kalirajan (2007), Drysdale et al. (2012), and Kumar and Prabhakar (2017), potential export can be understood as maximum possible quantity that Vietnam can export to the EU, given the current level of determinants of export, considering that there are no restrictions. In other words, the potential can be conceived of what the Vietnam's export would be in the hypothetical frictionless case. By contrast, actual export is given by the current level of the determinants of Vietnam's export to the EU, with existing level of restriction. The ratio of actual export to potential export is then defined as export efficiency. The difference between potential and actual export is then interpreted as export inefficiency or technical inefficiency, which is the unexploited potential export.

To this date, potential trade has been discussed at length in the international trade literature. From the methodological point of view, these studies can be classified into two groups. The first group of studies tried to estimate either the trade efficiency score, the potential trade, or both. Within this group, two approaches have been proposed to estimate the trade efficiency and potential trade. The first approach is based on the conventional gravity model (Egger, 2002; Gros and Gonciarz, 1996; Nilsson, 2000). However, the problem arising from this approach is that the least square method estimates the central value of the data set, while potential trade is involved in the upper limit of the dataset. The second approach relies on the stochastic frontier analysis (Viorica, 2015), which deals with the upper limit of the dataset. The second group of studies went beyond the estimation of the potential trade. They added another regression equation to analyze the determinants of trade efficiency, which is calculated based on the stochastic frontier analysis (Drysdale et al., 2012). They found that economic freedom, membership in trading blocs, and rule of origin are important determinants of trade efficiency.

Our extensive review of the literature indicated two potential knowledge gaps. First, there has been no study on the impact of financial market development, trade freedom, technological readiness, and labor freedom on Vietnam's potential agricultural exports. Secondly, the problem of endogeneity in analyzing the determinants of potential trade has never been solved. Given such knowledge gap in the existing literature, this study aims at quantifying the determinants of Vietnam's potential exports to the EU, taking agricultural commodities as a case study. In order to achieve this, the study is guided by the following specific research objectives:

- To systematize the theories on export efficiency and potential exports.

- To estimate Vietnam's potential agricultural exports to the EU.

- To quantify the determinants of Vietnam's potential agricultural exports to the EU.

\footnotetext{
${ }^{1}$ Just after China, which accounted for $24.9 \%$ of Vietnam's total agricultural exports.

${ }^{2}$ Leading export commodities include coffee, pepper, vegetables, fruit, and rice.

${ }^{3}$ The authors' computation based on the data from WITS.
} 


\section{MATERIALS AND METHODS}

\subsection{Theoretical framework}

As a convention, this study involves in two related equations. The first equation deals with factors influencing Vietnam's agricultural exports to the EU (trade equation), whose estimates are used to derive Vietnam's export efficiency scores and potential agricultural exports. The second equation focuses on quantifying the determinants of Vietnam's potential agricultural exports, whose values are gotten from the first equation (potential equation).

\subsubsection{Trade equation}

The trade equation is based on the gravity model of international trade, pioneered by Tinbergen (1962), Pöyhönen (1963), and Linnemann (1966), which was applied in a number of studies (Cantore and Cheng, 2018; Sanso et al., 1993; Sarker and Jayasinghe, 2007). According to the original model, the volume of trade between two countries, like the gravitational forces between two objects, depends directly on their masses and is inversely related to the distance between them. Subsequently, additional variables were added to the gravity model based on the theoretical ground and empirical evidence. Up to now, the gravity models are many, due to the types of variables that are introduced into the equations. However, an augmented gravity model generally includes: (i) economic size to represent export supply and import demand (Abeliansky and Hilbert, 2017; Zheng et al., 2017; Wireko-Manu and Amamoo, 2017; Liu et al., 2018), (ii) geographical distance to exhibit transportation cost including cost of time, psychic distance, information and research costs, and economic horizon (Linnemann, 1966; Heo and Doanh, 2015), (iii) land areas to proxy for factor endowment (Frankel and Rose, 2002; Clarete et al., 2003), (iv) landlocked status to reflect transaction costs resulting from the quality of infrastructure and services (Limão and Venables, 2001; Marteau et al., 2007), security (Faye et al., 2004), and transit fee (Snow et al., 2003), and (v) cultural distance to measure trade costs in relation to trust (Tadesse and White, 2008; Guiso et al., 2009), incomplete information and uncertainty (Cyrus, 2012), and communication (Hofstede, 1994; Gómez-mejia and Palich, 1997).

\subsubsection{Potential equation}

Four factors have been theoretically identified to have effects on the potential export. They include financial market development, trade freedom, technological readiness, and labor freedom. Firstly, the inclusion of the financial market development is based on the fact that the development of financial market promotes export performance (Niroomand et al., 2014). This is because good financial market facilitates exporters in the exporting countries and importers in the importing countries to obtain necessary loans for their export and import activities. In addition, the development of financial market promotes faster production, which increases export capacity. Secondly, the impact of trade barriers, as measured by trade freedom, on trade flows have been frequently cited in the international trade literature. Trade barriers consisting of tariff and nontariff barriers restrict bilateral trade flows because they lead to decreased quantity and increased price of imported goods (Winkelmann and Winkelmann, 1997; Ching et al., 2004; Winchester, 2009; Jordaan, 2017; Khorana and Narayanan, 2017; Cheong et al., 2018; Tanimu and Akujuru, 2018). Since these barriers hinder bilateral trade, they also prevent a country from reaching its potential export. Thirdly, technological readiness represents the availability of technological resources of a country such as development of information and communication technology (ICT) and technological adoption. ICT decreases the cost of trade (Hortaçsu et al., 2009; Lendle and Vézina, 2015). Also, technological progress facilitates the development of new products and processes, which helps the country to become more competitive in the international market (Chung et al., 2013; Somers, 1962). Fourthly, labor freedom includes various aspects of the legal and regulatory framework of a country's labor market. Rules of maximum working hours and minimum wage can reduce productivity, and increase the costs to produce and export. In addition, regulations on labor standards can be used as protectionist measures in international trade. For example, regulation on the right to organize and collective bargaining have negative effects on 
exports (Hasnat, 2002). Hence, it can be assumed that more government intervention, means less free labor market, which obstructs the country's exports to attain its potential level. In summary, based on the theoretical analysis presented above, we can say that, financial market development, trade freedom, technological readiness, and labor freedom have positive impacts on potential exports.

\subsection{Research Methodology}

\subsubsection{Analytical models and methods of estimation}

This study used stochastic frontier analysis to calculate the technical efficiency of Vietnam's agricultural exports to the EU. Based on technical efficiency, we continued the assessing of the potential exports. This calculation was then used as the basis in analyzing the factors influencing the potential export of Vietnam's agricultural commodities to the EU in the following stage.

To start with, the gravity model was applied. The model can be written as:

$$
\begin{aligned}
\ln E X_{i j, t}=\beta_{0}+ & \beta_{1} \ln \left(G D P_{i, t} \times G D P_{j, t}\right)+\beta_{2} \operatorname{lnDIST}_{i j}+\beta_{3} L_{O C K_{j}}+\beta_{4} \ln A G R I_{-} A R E A_{j, t} \\
& +\beta_{5} C U L_{-} D I S T_{i j}+\varepsilon_{i j, t} \\
& \ldots \ldots \ldots \ldots \ldots \ldots \ldots \ldots \ldots \ldots \ldots \ldots \ldots \ldots
\end{aligned}
$$

Where:

- $\quad$ In is natural logarithm; $i$ and $j$ indicate country $i$ (Vietnam) and country $j$ (Vietnam's trading partner), respectively; $t$ denotes year $t$;

- $E X_{i j, t}$ is the value of Vietnam's agricultural export to country $j$ in year $t$, measured in thousands of US Dollars.

- $G D P_{i, t}$ and $G D P_{j, t}$ are the Gross Domestic Product of Vietnam and country $j$ in year $t$ respectively, measured in billions of US Dollars.

- $\quad D I S T_{i j}$ is geographical distance between the capital city of Vietnam and the capital city of country $j$, measured in $\mathrm{km}$.

- $\quad L O C K_{j}$ is a dummy variable, which equals 1 if country $j$ is landlocked and zero otherwise.

- $A G R I \_A R E A_{j, t}$ is ratio of agricultural land to total land area of country $j$, measured in percentage.

- $\quad C U L \_D I S T_{i j}$ is cultural distance between Vietnam and country $j$. Drawing on Kogut and Singh (1988), the index is calculated as follows:

$$
C U L_{-} D I S T_{i j}=\frac{1}{4} \sum_{k=1}^{4} \frac{\left(D_{k i}-D_{k j}\right)^{2}}{\operatorname{Var}(k)}
$$

Where: $D_{k i \text { and }} D_{k j}$ are the $\mathrm{k}^{\text {th }}$ cultural dimension of Vietnam and country $j$, respectively. $\operatorname{Var}(k)$ is variance of $\mathrm{k}^{\text {th }}$ cultural dimension. There are 4 dimensions used to measure cultural distance: power distance, individualism, masculinity, and uncertainly avoidance.

- $\varepsilon_{i j, t}$ is the error term

In order to estimate Vietnam's export efficiency with the EU, we apply the stochastic frontier model introduced by Aigner et al. (1977) and Meeusen and van Den Broeck (1977). To do so, the error term is decomposed into two components. The first component is pure random term $\left(v_{i j, t}\right)$, which is a two-sided error term with a symmetric distribution. The second component is the singlesided error term $\left(u_{i j, t}\right)$, which is a measurement of inefficiency and strictly non-negative. The stochastic frontier model is written as follows:

$$
\ln E X_{i j, t}=\beta_{0}+\beta_{1} \ln \left(G D P_{i, t} \times G D P_{j, t}\right)+\beta_{2} \ln D I S T_{i j}+\beta_{3} L O C K_{j}+\beta_{4} \ln A G I_{-} A R E A_{j, t}
$$




$$
+\beta_{5} C U L_{-} D I S T_{i j}+\left(v_{i j, t}-u_{i j, t}\right)
$$

Following Battese and Coelli (1988), export efficiency is equivalent to the ratio of Vietnam's actual export to EU in any given year $t$ to the corresponding export when $u_{i j, t}$ is zero. Therefore, Vietnam's export efficiency to a specific EU country can be computed as follows:

$$
\text { Export efficiency }_{i j, t}=\frac{\text { Actual Export }_{i j, t}}{\text { Potential Export }_{i j, t}}=\frac{\exp \left(x_{i j t} \beta+v_{i j, t}-u_{i j, t}\right)}{\exp \left(x_{i j, t} \beta+v_{i j, t}\right)}=\exp \left(-u_{i j, t}\right)
$$

The value of export efficiency score ranges from zero to unity. Higher export efficiency implies that export volume is closer to the export frontier. A value of zero indicates scopes to raise actual export nearer to maximum level, whereas a value of unity implies that actual export coincides with potential export. Based on the estimated export efficiency scores, potential export can be calculated using the following simple equation:

$$
\text { Potential export }_{i j, t}=\frac{\text { Actual export }_{i j, t}}{\text { Export efficiency } y_{i j, t}}
$$

After the values of potential agricultural exports are estimated, the study employs another regression equation to analyze the determinants of Vietnam's potential agricultural exports to the EU as follows:

$$
\begin{aligned}
\ln E X_{-} P O_{i j, t}=\alpha_{0}+ & \alpha_{1} \ln E X_{-} P O_{i j, t-1}+\alpha_{2}\left(F I_{-} M A R_{i, t} \times F I_{-} M A R_{j, t}\right)+ \\
& +\alpha_{3} T R A D E E_{-} F R E E_{j, t} \\
& \alpha_{4} T E C H_{i, t}+\alpha_{5} L A B O R_{-} F R E E_{i, t}+\mu_{i j, t}
\end{aligned}
$$

Where:

- $E X_{-} P O_{i j, t}$ is the value of Vietnam's potential agricultural exports to country $j$ in year $t$; measured in thousands of US Dollars.

- FI_MAR $R_{i, t}$ and $F I_{-} M A R_{j, t}$ are the financial market development of country $i$ and country $j$ in year $t$, respectively. Its value ranges from 1 to 7 (best). This index is created by The World Economic Forum based on following elements: efficiency, trustworthiness, and confidence.

- TRADE_FREE $E_{j, t}$ is the trade freedom of country $j$ in year $t$. Its value ranges from 0 to 100 (free). This index is measured by The Heritage based on the following equation:

$$
T R A D E_{-} F R E E_{j}=\left\{\left[\left(\operatorname{Tariff}_{\max }-\operatorname{Tariff}_{j}\right) /\left(\operatorname{Tariff}_{\max }-\operatorname{Tariff}_{\min }\right)\right] * 100\right\}-N T B_{j}
$$

In which: Tariff $f_{\max }$ and Tariff min $_{\text {min }}$ represent the upper and lower limits of tariff rates (\%); Tariff represents the weighted average tariff rate $(\%)$ of country $j$. NTB is non-tariff barriers. It has five scales: $20,15,10,5$ and 0 respectively corresponding to NTBs being employed extensively across many commodities, NTBs being popular across many commodities, NTBs being used on certain commodities, NTBs being used on few commodities, and NTBs being not totally used.

- $\quad \mathrm{TECH}_{i, t}$ is the extent of technological readiness of country $i$ in year $t$. It comprises technological adoption, and the use of information and communication technology. The data of these components were gained from International Telecommunication Union and converted to scale of 1 to 7 (best) by the World Economy Forum.

- $\quad L A B O R \_F R E E_{i, t}$ is the extent of labor freedom of country $i$ in year $t$. Its value ranges from 0 to 100 (free). This index includes following components: ratio of minimum wage to the average value added per worker; hindrance to hiring additional workers; rigidity of hours; difficulty of firing redundant employees; legally mandated notice period; and mandatory severance pay. Each component is transferred to scale of 0 to 100 based on the equation as below: 


$$
\text { Factor }_{\text {Score }}=50 \times \text { factor }_{\text {average }} / \text { factor }_{i}
$$

Where: country $i$ data are calculated relative to the world average and then multiplied by 50 . The total score is averaged for country $i$ based on scores of six factors.

- $\mu_{i j, t}$ is the error term.

The equation 3 is dynamic in nature. Therefore, we opt for system GMM estimator to analyze the determinants on Vietnam's potential agricultural exports to the EU. The approach allows us to overcome the limitations of the panel data including endogeneity, serial correlations, heteroskedasticity, and omitted important variables. Moreover, we use the FGLS method with the panel selection to test the robustness of the results in the GMM model.

\subsection{Data}

We used the panel data for 89 countries from the period of 2006-2016. The description of all used variables is presented in Table 1.

Table 1: The description of variables

\begin{tabular}{|c|c|c|}
\hline Variables & Definition & Source \\
\hline EX & $\begin{array}{l}\text { The value of Vietnam's agricultural } \\
\text { exports }\end{array}$ & World Integrated Trade Solution \\
\hline GDP & Gross domestic product & $\begin{array}{l}\text { IMF World Economic } \text { Outlook } \\
\text { Database }\end{array}$ \\
\hline DIST & Geographical distance & $\begin{array}{l}\text { Center for Prospective Studies and } \\
\text { International Information (CEPII) }\end{array}$ \\
\hline LOCK & Landlocked status & $\begin{array}{l}\text { Center for Prospective Studies and } \\
\text { International Information (CEPII) }\end{array}$ \\
\hline AGRI_AREA & $\begin{array}{l}\text { The ratio of agricultural land to } \\
\text { total land area }\end{array}$ & The World Bank \\
\hline CUL_DIST & Cultural distance & $\begin{array}{l}\text { Calculated according to data from } \\
\text { hofstede-insights.com }\end{array}$ \\
\hline EX_PO & $\begin{array}{l}\text { Value of Vietnam's potential } \\
\text { agricultural exports }\end{array}$ & Authors' estimated results \\
\hline FI_MAR & Financial market development & The World Economy Forum \\
\hline TRADE_FREE & Trade freedom & The Heritage \\
\hline TECH & Extent of technological readiness & The World Economy Forum \\
\hline LABOR_FREE & Extent of labor freedom & The Heritage \\
\hline
\end{tabular}

\section{RESULTS AND DISCUSSION}

The trade equation has 979 observations and potential equation has 280 observations. The summary statistics of variables used in the trade equation and potential equation is shown in Appendix 1. The result of Levin-Lin-Chu test for stationarity in panel data are shown in Table 2. The test results reject strongly null hypothesis that all the panels contain a unit root. It means that all variables are stationary at the original level, which is a precondition for avoiding false regression results. 
Table 2: Results of Levin-Lin-Chu unit root test

\begin{tabular}{lccc}
\hline Explanatory variables & Unadjusted t & Adjusted $\mathbf{t}^{*}$ & Probability $^{\mathbf{4}}$ \\
\hline $\ln \mathrm{X}_{\mathrm{i}, \mathrm{t}}$ & -21.276 & -15.622 & 0.000 \\
$\mathrm{Ln}\left(\mathrm{GDP}_{\mathrm{i}, \mathrm{t}} \times \mathrm{GDP}_{\mathrm{j}, \mathrm{t}}\right)$ & -18.287 & -17.211 & 0.000 \\
LnAGRI_AREA $_{\mathrm{j}, \mathrm{t}}$ & -27.700 & -23.707 & 0.000 \\
$\left(\mathrm{FI} M \mathrm{R}_{\mathrm{i}, \mathrm{t}} \times \mathrm{FI} \mathrm{MAR}_{\mathrm{j}, \mathrm{t}}\right)$ & -17.194 & -13.326 & 0.000 \\
TRADE_FREE & -76.611 & -75.668 & 0.000 \\
\hline
\end{tabular}

Table 3 shows estimation results from the stochastic frontier model. The results of the estimation corresponded to the theory used in most of the studied variables, namely: the economic size represented by GDP and the change in Vietnam's agricultural export, in the same direction. Whereas, geographic distance, the proportion of agricultural land to the total land area of the importing country, landlocked status, and cultural distance between the exporting country and the importing country have negative relationship with the export of Vietnam's agricultural commodities.

Table 3: Results of the stochastic frontier model

\begin{tabular}{lccc}
\hline Explanatory variables & Coefficient & Std. Error & Probability \\
\hline Constant & $10.921^{* *}$ & 0.815 & 0.000 \\
Ln $\left(G D P_{i, t} \times G^{*} P_{j, t}\right)$ & $0.896^{* *}$ & 0.026 & 0.000 \\
LnDIST $_{\mathrm{ij}}$ & $-0.991^{* *}$ & 0.081 & 0.000 \\
LOCK $_{\mathrm{j}}$ & $-0.464^{* *}$ & 0.114 & 0.000 \\
LnAGI_AREA $_{\mathrm{j}, \mathrm{t}}$ & $-0.065^{* *}$ & 0.012 & 0.000 \\
CUL_DIST & 0.047 & 0.000 \\
Log likelihood & $-0.233^{* *}$ & -1556.481 & \\
Wald chi2 & & 1970.99 & \\
Observations & & 979 & \\
\hline
\end{tabular}

** Significant at the 0.01 level

Table 4 shows the results of the calculated technical efficiency of Vietnam's agricultural exports to the EU. Technical efficiencies are quite stable, 11 out of 28 countries experience a slight increase in their technical efficiency ( $9.1 \%$ on average during the period). Only Luxembourg's technical efficiency increased by 44\%; however, the proportion of Vietnam's agricultural exports to this country is very small, only below $1 \%$. The technical efficiency of the remaining 17/28 countries decreased moderately (the average decrease during the period was just $5.1 \%$ ). At the end of the period (2016), technical efficiencies increased by the highest margin at $73 \%$ (Belgium). This shows that the potential for Vietnam's agricultural export growth to the EU is still very high.

Table 4: Technical efficiency of agricultural export from Vietnam to the EU

\begin{tabular}{lccccccccccc}
\hline Countries & $\mathbf{2 0 0 6}$ & $\mathbf{2 0 0 7}$ & $\mathbf{2 0 0 8}$ & $\mathbf{2 0 0 9}$ & $\mathbf{2 0 1 0}$ & $\mathbf{2 0 1 1}$ & $\mathbf{2 0 1 2}$ & $\mathbf{2 0 1 3}$ & $\mathbf{2 0 1 4}$ & $\mathbf{2 0 1 5}$ & $\mathbf{2 0 1 6}$ \\
\hline EU market & 0.64 & 0.65 & 0.66 & 0.64 & 0.64 & 0.66 & 0.65 & 0.64 & 0.64 & 0.62 & 0.61 \\
Austria & 0.75 & 0.76 & 0.76 & 0.71 & 0.72 & 0.73 & 0.72 & 0.73 & 0.72 & 0.72 & 0.71 \\
Belgium & 0.76 & 0.75 & 0.79 & 0.76 & 0.76 & 0.77 & 0.76 & 0.76 & 0.75 & 0.74 & 0.73 \\
Bulgaria & 0.39 & 0.43 & 0.51 & 0.48 & 0.44 & 0.41 & 0.43 & 0.44 & 0.47 & 0.39 & 0.35 \\
Croatia & 0.28 & 0.33 & 0.38 & 0.34 & 0.37 & 0.37 & 0.39 & 0.31 & 0.34 & 0.26 & 0.23 \\
Cyprus & 0.21 & 0.28 & 0.38 & 0.40 & 0.41 & 0.42 & 0.34 & 0.28 & 0.32 & 0.24 & 0.24 \\
Czech Republic & 0.54 & 0.59 & 0.65 & 0.64 & 0.62 & 0.62 & 0.57 & 0.54 & 0.52 & 0.50 & 0.50 \\
Denmark & 0.60 & 0.63 & 0.64 & 0.64 & 0.64 & 0.65 & 0.64 & 0.63 & 0.65 & 0.61 & 0.62 \\
Estonia & 0.50 & 0.46 & 0.54 & 0.56 & 0.50 & 0.51 & 0.46 & 0.47 & 0.41 & 0.38 & 0.43 \\
\hline
\end{tabular}

${ }^{4}$ The p-value of adjusted $t^{*}$ 


\begin{tabular}{llllllllllll}
\hline Finland & 0.26 & 0.32 & 0.41 & 0.27 & 0.28 & 0.33 & 0.33 & 0.29 & 0.28 & 0.27 & 0.30 \\
France & 0.58 & 0.60 & 0.61 & 0.59 & 0.58 & 0.60 & 0.60 & 0.59 & 0.61 & 0.57 & 0.56 \\
Germany & 0.65 & 0.67 & 0.67 & 0.66 & 0.66 & 0.68 & 0.68 & 0.66 & 0.66 & 0.64 & 0.64 \\
Greece & 0.43 & 0.48 & 0.48 & 0.50 & 0.49 & 0.52 & 0.53 & 0.49 & 0.49 & 0.46 & 0.46 \\
Hungary & 0.74 & 0.75 & 0.67 & 0.65 & 0.67 & 0.68 & 0.65 & 0.63 & 0.65 & 0.66 & 0.66 \\
Ireland & 0.23 & 0.30 & 0.23 & 0.29 & 0.34 & 0.31 & 0.31 & 0.29 & 0.32 & 0.30 & 0.27 \\
Italy & 0.66 & 0.68 & 0.69 & 0.67 & 0.67 & 0.69 & 0.69 & 0.68 & 0.67 & 0.65 & 0.64 \\
Latvia & 0.33 & 0.38 & 0.44 & 0.48 & 0.45 & 0.46 & 0.41 & 0.40 & 0.43 & 0.42 & 0.38 \\
Lithuania & 0.34 & 0.49 & 0.58 & 0.61 & 0.52 & 0.48 & 0.49 & 0.41 & 0.45 & 0.44 & 0.42 \\
Luxembourg & 0.17 & 0.04 & 0.15 & 0.40 & 0.44 & 0.14 & 0.47 & 0.43 & 0.62 & 0.60 & 0.61 \\
Malta & 0.25 & 0.43 & 0.51 & 0.48 & 0.49 & 0.55 & 0.50 & 0.50 & 0.53 & 0.37 & 0.37 \\
Netherlands & 0.72 & 0.73 & 0.73 & 0.72 & 0.72 & 0.74 & 0.73 & 0.71 & 0.72 & 0.71 & 0.71 \\
Poland & 0.69 & 0.69 & 0.71 & 0.67 & 0.66 & 0.66 & 0.62 & 0.64 & 0.63 & 0.61 & 0.59 \\
Portugal & 0.49 & 0.54 & 0.59 & 0.63 & 0.62 & 0.64 & 0.63 & 0.64 & 0.62 & 0.61 & 0.60 \\
Romania & 0.42 & 0.41 & 0.45 & 0.46 & 0.45 & 0.44 & 0.40 & 0.39 & 0.36 & 0.32 & 0.29 \\
Slovak Republic & 0.69 & 0.68 & 0.66 & 0.68 & 0.67 & 0.68 & 0.65 & 0.66 & 0.61 & 0.57 & 0.54 \\
Slovenia & 0.47 & 0.53 & 0.53 & 0.54 & 0.55 & 0.54 & 0.46 & 0.48 & 0.48 & 0.40 & 0.44 \\
Spain & 0.64 & 0.67 & 0.67 & 0.65 & 0.64 & 0.66 & 0.65 & 0.64 & 0.64 & 0.61 & 0.59 \\
Sweden & 0.42 & 0.46 & 0.48 & 0.47 & 0.47 & 0.48 & 0.49 & 0.44 & 0.43 & 0.42 & 0.40 \\
United Kingdom & 0.60 & 0.64 & 0.64 & 0.61 & 0.63 & 0.66 & 0.65 & 0.64 & 0.65 & 0.64 & 0.64 \\
\hline
\end{tabular}

Source: Authors' own calculations

However, there are some special cases where the technical efficiency increased or decreased sharply during the study period. Typically, the technical efficiency of Vietnam's agricultural exports to Luxembourg increased dramatically by $44 \%$ (from $17 \%$ to $61 \%$ ). This change pushed Luxembourg from the lowest technical efficiency to the eighth position among the EU's members. On the contrary, the biggest drop was witnessed by the Slovak Republic with 15\% (from 69\% to $54 \%$ ). This decline pulled Slovak Republic, from the country with the sixth highest technical efficiency of Vietnam's agricultural exports among EU's members at the beginning of the period, to the fifteenth at the end of the period.

From the calculation of the technical efficiency in Table 4, we calculated Vietnam's potential agricultural exports to the EU, whose results are shown in Table 5. Calculated data shows that Vietnam's potential agricultural exports to the EU have been high and shown signs of increasing. Moreover, the EU member countries which have the largest potential exports for Vietnam's agricultural exports are: Germany (1750.85 million USD), the United Kingdom (736.08 million USD), Spain (731.09 million USD), Italy (711.45 million USD), France (694.39 million USD), and the Netherlands (677.69 million USD), all in 2016. The countries having the smallest potential are: Malta (more than 2.58 million USD), Hungary, Latvia, Slovenia, and Slovak Republic. Potential exports of all these countries were below 20 million USD in 2016. The difference between these two groups of countries having the highest and lowest potential is very large. For example in 2016, the potential exports to the German market were 679 times more than potential exports to Malta. In 2006, the potential exports to the German market were 1,198 times more than potential exports to Malta. This difference is mainly due to the impact of the economic size represented by the GDP between the two groups. 
Table 5: The potential for Vietnam's agricultural exports to the EU (Million USD)

\begin{tabular}{|c|c|c|c|c|c|c|c|c|c|c|c|}
\hline Country & 2006 & 2007 & 2008 & 2009 & 2010 & 2011 & 2012 & 2013 & 2014 & 2015 & 2016 \\
\hline EU market & 3143.74 & 4184.49 & 4979.92 & 4380.31 & 4790.5 & 6088.43 & 6239.43 & 6106.88 & 6676.12 & 6595.48 & 7015.26 \\
\hline Austria & 58.05 & 78.05 & 93.13 & 45.50 & 55.49 & 73.83 & 74.44 & 84.55 & 88.85 & 97.63 & 90.58 \\
\hline Belgium & 199.82 & 199.85 & 367.12 & 263.03 & 267.52 & 343.63 & 344.90 & 352.12 & 333.06 & 348.34 & 324.81 \\
\hline Bulgaria & 21.75 & 28.90 & 44.29 & 40.44 & 38.76 & 39.43 & 45.11 & 50.40 & 61.25 & 54.97 & 56.80 \\
\hline Croatia & 16.66 & 21.79 & 27.16 & 24.62 & 28.28 & 31.05 & 34.07 & 31.52 & 36.74 & 35.16 & 36.93 \\
\hline Cyprus & 9.41 & 12.17 & 16.55 & 17.84 & 20.17 & 22.84 & 20.45 & 19.78 & 22.77 & 22.64 & 25.28 \\
\hline Czech Republic & 44.03 & 65.33 & 104.76 & 99.20 & 100.17 & 111.10 & 90.37 & 85.24 & 86.90 & 92.63 & 105.49 \\
\hline Denmark & 33.45 & 47.78 & 57.36 & 58.31 & 60.86 & 75.06 & 72.92 & 77.24 & 94.98 & 79.36 & 94.43 \\
\hline Estonia & 10.16 & 10.97 & 15.44 & 15.54 & 13.60 & 16.48 & 15.14 & 17.33 & 16.27 & 17.08 & 22.42 \\
\hline Finland & 24.62 & 33.83 & 46.92 & 32.08 & 36.67 & 46.26 & 49.51 & 50.16 & 53.30 & 58.72 & 70.09 \\
\hline France & 313.52 & 400.90 & 449.40 & 413.74 & 447.89 & 563.46 & 591.98 & 608.03 & 742.83 & 664.17 & 694.39 \\
\hline Germany & 718.99 & 1005.96 & 1074.80 & 975.15 & 1144.05 & 1466.85 & 1641.84 & 1473.95 & 1621.38 & 1550.09 & 1750.85 \\
\hline Greece & 33.46 & 46.53 & 50.85 & 57.37 & 59.18 & 69.68 & 71.43 & 63.89 & 69.87 & 68.01 & 78.07 \\
\hline Hungary & 13.92 & 18.52 & 5.85 & 4.79 & 7.17 & 8.73 & 6.57 & 5.83 & 8.04 & 9.85 & 10.61 \\
\hline Ireland & 10.00 & 14.76 & 12.57 & 15.55 & 19.79 & 19.86 & 20.87 & 21.50 & 26.90 & 28.01 & 29.03 \\
\hline Italy & 345.61 & 460.42 & 581.73 & 481.59 & 511.60 & 691.80 & 734.04 & 684.22 & 717.79 & 683.21 & 711.45 \\
\hline Latvia & 4.22 & 6.03 & 7.99 & 8.29 & 7.97 & 9.40 & 9.00 & 9.52 & 11.87 & 13.15 & 12.88 \\
\hline Lithuania & 10.23 & 19.38 & 32.83 & 35.78 & 25.17 & 24.59 & 28.28 & 24.19 & 30.86 & 33.10 & 36.08 \\
\hline Luxembourg & 2.36 & 1.41 & 2.89 & 5.73 & 7.03 & 3.49 & 9.39 & 8.92 & 21.70 & 21.75 & 25.91 \\
\hline Malta & 0.60 & 1.37 & 2.19 & 1.96 & 2.28 & 3.37 & 2.81 & 3.09 & 3.91 & 2.32 & 2.58 \\
\hline Netherlands & 299.55 & 384.94 & 426.45 & 390.85 & 436.15 & 598.18 & 540.38 & 508.12 & 581.94 & 628.24 & 677.69 \\
\hline Poland & 206.69 & 254.48 & 339.81 & 259.40 & 261.97 & 313.05 & 250.72 & 309.93 & 323.51 & 336.14 & 332.32 \\
\hline Portugal & 32.53 & 46.97 & 66.57 & 86.24 & 90.28 & 106.91 & 108.77 & 121.85 & 119.72 & 122.69 & 127.72 \\
\hline Romania & 43.74 & 51.86 & 68.91 & 70.41 & 73.99 & 77.96 & 76.49 & 81.08 & 83.40 & 83.86 & 89.16 \\
\hline Slovak Republic & 18.12 & 21.86 & 21.00 & 25.45 & 25.50 & 32.77 & 26.88 & 33.21 & 24.74 & 21.81 & 20.76 \\
\hline Slovenia & 8.43 & 12.58 & 14.46 & 14.67 & 16.83 & 17.86 & 14.21 & 16.23 & 17.87 & 15.58 & 19.72 \\
\hline Spain & 402.79 & 549.82 & 629.71 & 565.23 & 562.97 & 718.35 & 732.53 & 721.08 & 764.55 & 724.72 & 731.09 \\
\hline Sweden & 38.75 & 51.43 & 61.65 & 59.69 & 69.08 & 79.93 & 91.30 & 84.31 & 88.89 & 95.84 & 102.03 \\
\hline United Kingdom & 222.26 & 336.60 & 357.51 & 311.88 & 400.07 & 522.50 & 535.03 & 559.59 & 622.24 & 686.44 & 736.08 \\
\hline
\end{tabular}

Source: Authors' own calculations 
To verify suitability and effectiveness of the model GMM, AR (2) and Sargan tests were used. AR (2) test could not reject the null hypothesis of no autocorrelation. At the same time, Sargan test result showed that all instruments used in the equation (3) were valid. In summary, using the GMM model with instrumental variables in this case is suitable and efficient. Moreover, FGLS regression results affirmed robustness of GMM regression results.

Table 6: Results of Vietnam's potential agriculture export

\begin{tabular}{|c|c|c|}
\hline Explanatory variables & FGLS & GMM \\
\hline $\operatorname{lnEX} \mathrm{PO}_{\mathrm{ij}, \mathrm{t}-1}$ & & $\begin{array}{c}0.954 * * \\
(0.010)\end{array}$ \\
\hline$\left(\mathrm{FI} \mathrm{MAR}_{\mathrm{i}, \mathrm{t}} \times \mathrm{FI} \mathrm{MAR}_{\mathrm{j}, \mathrm{t}}\right)$ & $\begin{array}{c}0.036 * * \\
(0.011)\end{array}$ & $\begin{array}{c}0.018 * * \\
(0.001)\end{array}$ \\
\hline TRADE_FREE $\mathrm{j}_{\mathrm{j}, \mathrm{t}}$ & $\begin{array}{r}0.019 * * \\
(0.005)\end{array}$ & $\begin{array}{r}0.050 * * \\
(0.007)\end{array}$ \\
\hline $\mathrm{TECH}_{\mathrm{i}, \mathrm{t}}$ & $\begin{array}{c}0.130 \\
(0.073)\end{array}$ & $\begin{array}{r}0.115^{* *} \\
(0.034)\end{array}$ \\
\hline LABOR_FREE $\mathrm{i}_{\mathrm{i}, \mathrm{t}}$ & $\begin{array}{c}0.001 \\
(0.005)\end{array}$ & $\begin{array}{r}0.028 * * \\
(0.003)\end{array}$ \\
\hline Constant & $\begin{array}{l}7.867 * * \\
(0.548)\end{array}$ & $\begin{array}{c}-6.247 * * \\
(0.702)\end{array}$ \\
\hline Number of Observations & 308 & 280 \\
\hline $\begin{array}{ll}\text { AR (2) Test } & z \\
P r>z\end{array}$ & & $\begin{array}{l}-0.36 \\
0.721\end{array}$ \\
\hline $\begin{array}{l}\text { Chi }(2) \\
\text { Prob > chi2 }\end{array}$ & & $\begin{array}{l}23.85 \\
0.202\end{array}$ \\
\hline
\end{tabular}

Note: Standard errors in parentheses

${ }^{* *}$ Significant at the 0.01 level

Table 6 shows that all variables are statistically significant. At the same time, they are consistent with theory: the more developed the financial market, the higher Vietnam's potential agricultural exports to the EU. This result is consistent with Niroomand et al. (2014). The freer the trade, the higher Vietnam's potential agricultural export to the EU. This finding is supported by Riley and Miller (2015). Similarly, technological readiness of Vietnam positively impacts on its agricultural exports to the EU. And finally, the higher the freedom of the labor market in Vietnam, the higher Vietnam's potential agricultural exports to the EU.

\section{CONCLUSION}

This study used stochastic frontier analysis to estimate Vietnam's potential agricultural exports to the EU. In addition, a system GMM approach was used to analyze the determinants of the estimated potential agricultural exports of Vietnam. The major findings are summarized as follows. Generally, potential agricultural exports of Vietnam to the EU have been high and on an upward trend. The countries with the highest potentials for Vietnam's agricultural exports are Germany, the United Kingdom, Spain, Italy, France, and the Netherlands. In terms of value, it is possible to increase agricultural export value to these markets by $30-40 \%$. In addition, there are positive correlations between financial market development, trade freedom, technological readiness, labor freedom and Vietnam's potential agricultural exports to the EU.

From the above conclusions, we propose some measures through which Vietnam's agricultural exports can attain its potential level. First, it is necessary to improve the efficiency and stability of the financial market of the Vietnam, as well as maintain a healthy macroeconomic environment. Moreover, Vietnam should actively participate in FTAs in order to reduce trade barriers relating to 
agricultural exports. It is also important to reform regulations of the Vietnamese labor market to increase the freedom level in the labor market. Finally, the Vietnamese government needs to invest more in technological development to raise the agricultural exports of the country.

Funding: This article is the product of Thai Nguyen University's Scientific and Technological Project
carried out in 2017. The project entitled "Analysis potential export of Vietnam's agricultural products to
the European Union (EU) market" under code number: ĐH2017-TN08-07
Competing Interests: The authors declared that they have no conflict of interests.
Contributors/Acknowledgement: The authors would like to express our honest appreciation to the Thai
Nguyen University for their financial support.
Views and opinions expressed in this study are the views and opinions of the authors, Asian Journal of
Agriculture and Rural Development shall not be responsible or answerable for any loss, damage or liability
etc. caused in relation to/arising out of the use of the content.

\section{References}

Abeliansky, A. L., \& Hilbert, M. (2017). Digital technology and international trade: Is it the quantity of subscriptions or the quality of data speed that matters? Telecommunications Policy, 41(1), 35-48. doi:10.1016/j.telpol.2016.11.001.

Aigner, D., Lovell, C. A. K., \& Schmidt, P. (1977). Formulation and estimation of stochastic frontier production function models. Journal of Econometrics, 6(1), 21-37. doi:10.1016/0304-4076(77)90052-5.

Battese, G. E., \& Coelli, T. J. (1988). Prediction of firm-level technical efficiencies with a generalized frontier production function and panel data. Journal of Econometrics, 38(3), 387-399. doi:10.1016/0304-4076(88)90053-x.

Cantore, N., \& Cheng, C. F. C. (2018). International trade of environmental goods in gravity models. J Environ Manage, 223, 1047-1060. doi:10.1016/j.jenvman.2018.05.036.

Center for Prospective Studies and International Information. Retrieved from http://www.cepii.fr/.

Cheong, J., Kwak, D. W., \& Tang, K. K. (2018). The trade effects of tariffs and non-tariff changes of preferential trade agreements. Economic Modelling, 70, 370-382. doi:10.1016/j.econmod.2017.08.011.

Ching, S., Wong, C. Y. P., \& Zhang, A. (2004). Non-tariff barriers to trade in the pacific rim. Pacific Economic Review, 9(1), 65-73. doi:10.1111/j.1468-0106.2004.00237.x.

Chung, K. C., Fleming, P., \& Fleming, E. (2013). The impact of information and communication technology on international trade in fruit and vegetables in APEC. Asian-Pacific Economic Literature, 27(2), 117-130. doi:10.1111/apel.12028.

Clarete, R., Edmonds, C., \& Wallack, J. S. (2003). Asian regionalism and its effects on trade in the 1980s and 1990s. Journal of Asian Economics, 14(1), 91-129. doi: 10.1016/S10490078(02)00242-7.

Cyrus, T. L. (2012). Cultural distance and bilateral trade. Global Economy Journal, 12(4), 1-23. doi:10.1515/1524-5861.1895.

Drysdale, P., Huang, Y., \& Kalirajan, K. P. (2012). China's trade efficiency: measurement and determinants. In P. Drysdale, Z. Yunling, \& L. Song (Eds.), APEC and Liberalisation of the Chinese Economy (pp. 259-271). Canberra: ANU E Press.

Egger, P. (2002). An econometric view on the estimation of gravity models and the calculation of trade potentials. The World Economy, 25(2), 297-312. doi:10.1111/1467-9701.00432.

Faye, M. L., McArthur, J. W., Sachs, J. D., \& Snow, T. (2004). The challenges facing landlocked developing countries. Journal of Human Development, 5(1), 31-68. doi:10.1080/14649880310001660201.

Frankel, J., \& Rose, A. (2002). An estimate of the effect of common currencies on trade and income. The Quarterly Journal of Economics, 117(2), 437-466. doi:10.1162/003355302753650292. 
Gómez-mejia, L. R., \& Palich, L. E. (1997). Cultural diversity and the performance of multinational firms. Journal of International Business Studies, 28(2), 309-335. doi:10.1057/palgrave.jibs.8490103.

Gros, D., \& Gonciarz, A. (1996). A note on the trade potential of central and eastern Europe. European Journal of Political Economy, 12(4), 709-721. doi:10.1016/s01762680(96)00024-9.

GSO. (2017). Statistical yearbook of Vietnam. Ha Noi: General Statistics Office of Vietnam.

Guiso, L., Sapienza, P., \& Zingales, L. (2009). Cultural biases in economic exchange? Quarterly Journal of Economics, 124(3), 1095-1131. doi:10.1162/qjec.2009.124.3.1095.

Hasnat, B. (2002). The impact of core labour standards on exports. International Business Review, 11(5), 563-575. doi:10.1016/S0969-5931(02)00037-9.

Heo, Y., \& Doanh, N. K. (2015). Trade flows and IPR protection: a dynamic analysis of the experience of ASEAN-6 Countries. Asian International Studies Review, 16(1), 59-74. doi:10.16934/isr.16.1.201506.59.

Hofstede- Insights. Retrieved from https://www.hofstede-insights.com/.

Hofstede, G. (1994). The business of international business is culture. International Business Review, 3(1), 1-14. doi:10.1016/0969-5931(94)90011-6.

Hortaçsu, A., Martínez-Jerez, F. A., \& Douglas, J. (2009). The geography of trade in online transactions: evidence from eBay and Mercado Libre. American Economic Journal: Microeconomics, 1(1), 53-74. doi:10.1257/mic.1.1.53.

Jordaan, A. C. (2017). Impact of non-tariff measures on trade in Mauritius. Foreign Trade Review, 52(3), 185-199. doi:10.1177/0015732516681873.

Kalirajan, K. (2007). Regional Cooperation and Bilateral Trade Flows: An Empirical Measurement of Resistance. The International Trade Journal, 21(2), 85-107. doi:10.1080/08853900701266555.

Khorana, S., \& Narayanan, B. G. (2017). Modelling effects of tariff liberalisation on India's key export sectors: analysis of the EU-India Free Trade Agreement. Margin: The Journal of Applied Economic Research, 11(1), 1-22. doi:10.1177/0973801016676016.

Kogut, B., \& Singh, H. (1988). The effect of national culture on the choice of entry mode. Journal of International Business Studies, 19(3), 411-432. doi:10.1057/palgrave.jibs.8490394.

Kumar, S., \& Prabhakar, P. (2017). India's trade potential and free trade agreements: a stochastic frontier gravity approach. Global Economy Journal, 17(1), 1-19. doi:10.1515/gej-20160074

Lendle, A., \& Vézina, P. L. (2015). Internet technology and the extensive margin of trade: evidence from eBay in emerging economies. Review of Development Economics, 19(2), 375-386. doi:10.1111/rode.12148.

Limão, N., \& Venables, A. J. (2001). Infrastructure, geographical disadvantage, transport costs, and trade. The World Bank Economic Review, 15(3), 451-479. doi:10.1093/wber/15.3.451.

Linnemann, H. (1966). An Econometric Study of International Trade Flows. Amsterdam: NorthHolland Publishing Company.

Liu, A., Lu, C., \& Wang, Z. (2018). The roles of cultural and institutional distance in international trade: Evidence from China's trade with the Belt and Road countries. China Economic Review. doi:10.1016/j.chieco.2018.10.001.

Marteau, J. F., Raballand, G., \& Arvis, J. F. (2007). The cost of being landlocked: logistics costs and supply chain reliability. Washington, DC: The World Bank.

Meeusen, W., \& van Den Broeck, J. (1977). Efficiency estimation from cobb-Douglas production functions with composed error. International Economic Review, 18(2), 435-444. doi: $10.2307 / 2525757$.

Nilsson, L. (2000). Trade integration and the EU economic membership criteria. European Journal of Political Economy, 16(4), 807-827. doi:10.1016/s0176-2680(99)00060-9.

Niroomand, F., Hajilee, M., \& Al Nasser, O. M. (2014). Financial market development and trade openness: evidence from emerging economies. Applied Economics, 46(13), 1490-1498. doi:10.1080/00036846.2013.866207. 
Pöyhönen, P. (1963). A tentative model for the volume of trade between countries. Weltwirtschaftliches Archiv, 90, 93-100.

Riley, B., \& Miller, A. T. (2015). 2016 Index of economic freedom: yet more evidence of free trade's benefits. Retrieved from https://www.heritage.org/internationaleconomies/report/2016-index-economic-freedom-yet-more-evidence-free-trades-benefits.

Sanso, M., Cuairan, R., \& Sanz, F. (1993). Bilateral trade flows, the gravity equation, and functional form. The Review of Economics and Statistics, 75(2), 266-275. doi:10.2307/2109432.

Sarker, R., \& Jayasinghe, S. (2007). Regional trade agreements and trade in agri-food products: evidence for the European Union from gravity modeling using disaggregated data. Agricultural Economics, 37(1), 93-104. doi:10.1111/j.1574-0862.2007.00227.x.

Snow, T., Faye, M., McArthur, J., \& Sachs, J. (2003). Country case studies on the challenges facing landlocked developing countries. Human Development Report Office, Occasional paper, background paper for HDR 2003, United Nations Development Programme. New York.

Somers, J. C. (1962). Impact of technology on international trade. The American Journal of Economics and Sociology, 21(1), 69-76. doi:10.1111/j.1536-7150.1962.tb00825.x.

Tadesse, B., \& White, R. (2008). Does cultural distance hinder trade in goods? A Comparative Study of Nine OECD Member Nations. Open Economies Review, 21(2), 237-261. doi:10.1007/s11079-008-9090-8.

The Heritage. Retrieved from https://www.heritage.org/

Tinbergen, J. (1962). Shaping the world economy: suggestions for an international economic policy. New York: Twentieth Century Fund.

Viorica, E. D. (2015). Econometric analysis of foreign trade efficiency of E.U. Members Using Gravity Equations. Procedia Economics and Finance, 20, 670-678. doi:10.1016/s22125671(15)00122-7.

Winchester, N. (2009). Is there a dirty little secret? Non-tariff barriers and the gains from trade. Journal of Policy Modeling, 31(6), 819-834. doi:10.1016/j.jpolmod.2009.08.004.

Winkelmann, L., \& Winkelmann, R. (1997). The costs of non-tariff barriers to trade: Evidence from New Zealand. Review of World Economics, 133(2), 270-281. doi:10.1007/bf02707463.

World Economic Forum. Retrieved from http://reports.weforum.org/global-competitiveness-index2017-2018/competitiveness-rankings/\#series=NETUSERPCT.

World Integrated Trade Solution (2018). Retrieved from https://wits.worldbank.org/.

Zheng, Y., Shao, Y., \& Wang, S. (2017). The determinants of Chinese nonferrous metals imports and exports. Resources Policy, 53, 238-246. doi:10.1016/j.resourpol.2017.06.003. 


\section{Appendix}

Appendix 1: Summary of statistics

\begin{tabular}{|c|c|c|c|c|c|}
\hline Variables & Observations & Mean & Std. Dev & Min & $\overline{\operatorname{Max}}$ \\
\hline $\operatorname{lnEX} X_{\mathrm{ij}, \mathrm{t}}$ & 979 & 10.185 & 2.178 & 1.768 & 15.321 \\
\hline $\operatorname{Ln}\left(\mathrm{GDP}_{\mathrm{i}, \mathrm{t}} \times \mathrm{GDP}_{\mathrm{j}, \mathrm{t}}\right)$ & 979 & 9.925 & 1.823 & 4.829 & 15.137 \\
\hline $\operatorname{LnDIST}_{i j}$ & 979 & 8.958 & 0.646 & 6.772 & 9.850 \\
\hline $\mathrm{LOCK}_{\mathrm{j}}$ & 979 & 0.135 & 0.342 & 0.000 & 1.000 \\
\hline LnAGRI_AREA $_{\mathrm{j}, \mathrm{t}}$ & 979 & 0.718 & 3.050 & 0.002 & 2.925 \\
\hline CUL_DIST $T_{i j}$ & 979 & 2.957 & 1.242 & 1.000 & 6.335 \\
\hline$\left(\mathrm{FI} \_\overline{\mathrm{M}} \mathrm{AR}_{\mathrm{i}, \mathrm{t}} \times \mathrm{FI} \_\mathrm{MAR}, \mathrm{j}, \mathrm{t}\right)$ & 308 & 17.546 & 2.729 & 9.781 & 23.661 \\
\hline TRADE_FREE $E_{j, t}$ & 308 & 86.012 & 2.765 & 65.800 & 88.000 \\
\hline $\mathrm{TECH}_{\mathrm{i}, \mathrm{t}}$ & 308 & 3.230 & 0.291 & 2.594 & 3.582 \\
\hline LABOR_FREE $_{i, t}$ & 308 & 66.581 & 2.238 & 62.600 & 70.000 \\
\hline
\end{tabular}

Source: Statistical result

\section{Appendix 2: Countries included in the sample}

\begin{tabular}{clclcl}
\hline Order & \multicolumn{1}{c}{ Countries } & Order & \multicolumn{1}{c}{ Countries } & Order & \multicolumn{1}{c}{ Countries } \\
\hline 1 & Albania & 31 & Honduras & 61 & Peru \\
2 & Angola & 32 & Hong Kong SAR & 62 & Philippines \\
3 & Argentina & 33 & Hungary & 63 & Poland \\
4 & Australia & 34 & Iceland & 64 & Portugal \\
5 & Austria & 35 & India & 65 & Romania \\
6 & Bangladesh & 36 & Indonesia & 66 & Russia \\
7 & Belgium & 37 & Ireland & 67 & Saudi Arabia \\
8 & Brazil & 38 & Israel & 68 & Senegal \\
9 & Bulgaria & 39 & Italy & 69 & Serbia \\
10 & Canada & 40 & Jamaica & 70 & Sierra Leone \\
11 & Chile & 41 & Japan & 71 & Singapore \\
12 & China & 42 & Jordan & 72 & Slovak Republic \\
13 & Colombia & 43 & Kazakhstan & 73 & Slovenia \\
14 & Costa Rica & 44 & Korea & 74 & South Africa \\
15 & Croatia & 45 & Kuwait & 75 & Spain \\
16 & Cyprus & 46 & Latvia & 76 & Sri Lanka \\
17 & Czech Republic & 47 & Lebanon & 77 & Sweden \\
18 & Denmark & 48 & Lithuania & 78 & Switzerland \\
19 & Dominican Republic & 49 & Luxembourg & 79 & Tanzania \\
20 & Ecuador & 50 & Malaysia & 80 & Thailand \\
21 & Egypt & 51 & Malta & 81 & Trinidad and Tobago \\
22 & Estonia & 52 & Mexico & 82 & Turkey \\
23 & Ethiopia & 53 & Morocco & 83 & Ukraine \\
24 & Fiji & 54 & Mozambique & 84 & United Arab Emirates \\
25 & Finland & 55 & Nepal & 85 & United Kingdom \\
26 & France & 56 & Netherlands & 86 & United States \\
27 & Germany & 57 & New Zealand & 87 & Uruguay \\
28 & Ghana & 58 & Nigeria & 88 & Venezuela \\
29 & Greece & 59 & Pakistan & 89 & Zambia \\
30 & Guatemala & 60 & Panama & & \\
\hline & & & & &
\end{tabular}

